\title{
Analiza możliwości zastosowania zmodyfikowanego prototypu przystawki odorymetrycznej INiG - PIB na potrzeby wykonywania pomiarów metodą olfaktometrii dynamicznej
}

\begin{abstract}
W artykule opisano badania jakości zapachu próbek powietrza atmosferycznego z użyciem skonstruowanego w Zakładzie Nawaniania Paliw Gazowych Instytutu Nafty i Gazu - Państwowego Instytutu Badawczego prototypu przystawki odorymetrycznej INiG - PIB zmodyfikowanej do funkcji olfaktometrycznej. Badania zostały wykonane w celu potwierdzenia możliwości wykorzystania tego urządzenia do pomiarów zapachu próbek gazowych metodą olfaktometrii dynamicznej. Realizowane dotychczas prace badawcze w zakresie budowy oraz poszukiwania zastosowań dla układów analitycznych sprzężonych z przedmiotową przystawką [9-11] dotyczyły głównie pomiarów zapachu prowadzonych dla próbek gazów ziemnych oraz próbek powietrza zanieczyszczonego wykonywanych metodą odorymetryczną. Wynikiem tych badań było opracowanie oraz weryfikacja metody przeprowadzania tego rodzaju pomiarów dla obu wymienionych rodzajów próbek. Omówione w artykule wyniki badań stanowią kontynuację poszukiwań nowych zastosowań konstrukcji własnej INiG - PIB, jaką jest przystawka odorymetryczna (O INiG - PIB), przeznaczona głównie do współpracy z chromatografem gazowym. Znalezienie tych zastosowań wiązało się z koniecznością wprowadzenia nieznacznych modyfikacji konstrukcyjnych w urządzeniu i z weryfikacją poprawności wykonywanych przez nie pomiarów. W poniższym artykule przedstawiono zasady prowadzenia pomiarów olfaktometrycznych zapachu gazu w kontekście wymagań w stosunku do konstrukcji przeznaczonych do nich urządzeń pomiarowych. Na tej podstawie oraz opierając się na wynikach wcześniejszych prac badawczych, przyjęto założenia wprowadzenia niezbędnych modyfikacji prototypu przystawki odorymetrycznej INiG - PIB. Przeprowadzone badania zmodyfikowanego układu pozwoliły na zweryfikowanie poprawności jego działania według wymagań obowiązujących

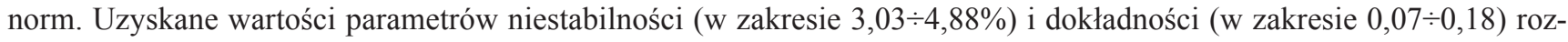
cieńczeń potwierdziły spełnianie przez urządzenie kryteriów badania zapachu metodą olfaktometryczną. Przy użyciu zmodyfikowanego układu wykonano także badania stężenia zapachowego syntetycznych mieszanin wybranych związków odorowych. Uzyskane wyniki pomiarów potwierdziły zgodność działania zaprojektowanego układu (O INiG - PIB) sprzężonego z chromatografem gazowym (GC-O INiG - PIB) z założeniami projektowymi oraz wykazały możliwość jego wykorzystania w badaniach jakości zapachowej powietrza atmosferycznego znormalizowaną metodą olfaktometrii dynamicznej.
\end{abstract}

Słowa kluczowe: odory, stężenie zapachowe, metody sensoryczne, olfaktometria dynamiczna.

\section{Analysis of the possibility of using the modified INIG - PIB odorimetry snap prototype, for measurements by dynamic olfactometry method}

The article describes research on the quality of the atmospheric air odor using the Oil and Gas Institute - National Research Institute (INiG - PIB) odorimetry snap prototype, adapted for measurements of gas scentl by dynamic olfactometry method. The research works carried out so far were in the field of construction as well as the search for new applications for analytical systems coupled with this adapter [9-11], mainly concerned odorimetric measurements of natural gas and polluted air samples. The result of this research was the development and verification of the measurement method for both mentioned types of samples. The discussed research results are a continuation of the new application search of INiG - PIB's odorimetric snap device (O INIG - PIB), dedicated mainly to cooperation with a gas chromatograph. This was connected with the necessity to introduce construction modifications and verify the correctness of the modified system measurements. The following article presents the principles of performing the gas scent olfactometric measurements in view of the requirements for the measuring 
devices' construction. Based on the established assumptions and previous research work results, necessary changes in the $\mathrm{INiG}$ - PIB odorimetric prototype construction were adopted. The modified system tests allowed to verify the correctness of its operation according to the applicable standards requirements. The obtained values of the dilutions instability (in the range of $3.03 \div 4.88 \%$ ) and accuracy (in the range of $0.07 \div 0.18$ ), confirmed that the device met the criteria for odor testing using the olfactometric method. Odour concentrations of synthetic mixtures of selected odorants were tested using the modified system. Obtained research results confirmed the compliance of the designed system (O INiG - PIB) coupled with a gas chromatograph (GC-O INiG - PIB), with design assumptions and the possibility of its use in the study of the fragrance quality of atmospheric air by a standardized dynamic olfactometry method.

Key words: odours, odour concentration, sensory methods, dynamic olfactometry.

\section{Wprowadzenie}

Odory, czyli nieprzyjemne zapachy związków chemicznych, są jednym z najbardziej uciążliwych zanieczyszczeń powietrza atmosferycznego. Z kolei jednymi z najbardziej uciążliwych źródeł emisji zapachu są wysypiska odpadów komunalnych, które oprócz odorów emitują także znaczne ilości metanu - gazu mającego wpływ na tzw. efekt cieplarniany $[3,14]$. Stanowią one jedno z najczęściej wskazywanych przez społeczeństwo źródeł uciążliwości zapachowej. Ocenę zapachowej jakości powietrza wykonuje się, określając oddziaływanie źródeł emisji odorantów na obszary, dla których ustalone zostały standardy zapachowe, definiowane jako wartość poziomu uciążliwości niepożądanych zapachów. Gdy nie istnieją regulacje prawne w zakresie uciążliwości zapachowej, egzekwowanie przez służby ochrony środowiska działań prowadzących do ograniczenia emisji nieprzyjemnych odorów jest znacznie utrudnione lub wręcz niemożliwe.

Próby prawnego uregulowania standardów zapachowej jakości powietrza podejmowane są od wielu lat zarówno w Polsce, jak i w innych krajach Unii Europejskiej. Do tej pory nie udało się jednak wypracować w tym zakresie standardów jed- nolitych dla całej Unii Europejskiej, jak również standardów krajowych. Jedynie norma europejska EN 13725:2003 (w Polsce PN-EN 13725:2007 Jakość powietrza. Oznaczanie stężenia zapachowego metoda olfaktometrii dynamicznej [17]) określa metodykę prowadzenia pomiarów kontrolnych stężenia zapachów wybraną metodą pomiaru, bez wskazania ,standardów" zapachowych powietrza. Podstawowym problemem, z jakim należy się zmierzyć, opisując światowe standardy jakości zapachowej powietrza, jest określenie miary, która mogłaby stanowić standard.

Do tej pory stworzone zostały stosowne unormowania dotyczące zapachowej jakości powietrza, obowiązujące w przemyśle i rolnictwie, a także w innych gałęziach gospodarki, m.in. w Niemczech, we Francji, w Holandii, Wielkiej Brytanii, Japonii, USA oraz Kanadzie. W wewnętrznych regulacjach państw, które ustanowiły standardy zapachowe powietrza, przyjęte są bardzo zróżnicowane kryteria służące ocenie i weryfikacji uciążliwości zapachu. Dla zobrazowania tych różnic w tablicy 1 zestawiono standardy przyjęte $\mathrm{w}$ trzech wybranych krajach europejskich, tj.: w Niemczech, Holandii i Wielkiej Brytanii [12].

\section{Przegląd metod badawczych zapachowej jakości powietrza}

W celu usystematyzowania metod, jakimi przeprowadza się badania jakości zapachowej powietrza, konieczne jest ustalenie modelu opisu ilościowego mierzonego parametru. Jest to trudne, gdyż zapach to wrażenie zmysłowe, a tym samym trudne do opisu ilościowego. W badaniach nad odorami oraz w próbach zmierzających do opisu i oceny zjawiska uciążliwości zapachowej uwzględniane są trzy podstawowe cechy zapachu:

- wyczuwalność - odnosi się do teoretycznego minimalnego stężenia odorantów (inaczej substancji zapachowych) stymulujących odczuwanie zapachu koniecznego do wyczucia przez połowę populacji,

- intensywność - wrażenie zmysłowe zależne od wielkości bodźca, który to wrażenie wywołuje,

- jakość hedoniczna - stopień odczuwalnej niechęci lub przyjemności zależny od intensywności i rodzaju odczuwanego zapachu [8].
Metody badania zapachu można podzielić zasadniczo na dwie grupy:

1) analizę sensoryczną - opierającą się na ocenie wrażeń zapachowych odbieranych przez ludzki zmysł powonienia, których wyniki przedstawiane są zwykle w postaci intensywności zapachowej, stężenia progowego czy stężenia zapachowego [5-7, 15];

2) analizę instrumentalną - obejmującą oznaczanie ilościowe poszczególnych składników mieszaniny gazowej odpowiedzialnych za jej zapach. Wśród metod tych wyróżnia się przede wszystkim: chromatografię gazową sprzężoną z olfaktometrią $[1,2,4,16]$.

Należy zaznaczyć, że niezwykle trudno jest badać zapachy przy użyciu samych metod instrumentalnych. Wynika to z faktu, że odczucie zapachu nie jest zależne tylko od samego jego charakteru, ale również od parametrów osobniczych, 
Tablica 1. Zestawienie standardów zapachowej jakości powietrza obowiązujących w wybranych krajach europejskich [12]

\begin{tabular}{|c|c|c|c|c|}
\hline \multirow[b]{2}{*}{ Kraj } & \multirow[b]{2}{*}{$\begin{array}{l}\text { Zakres obowiązywania } \\
\text { (sposób użytkowania terenu) }\end{array}$} & \multicolumn{3}{|c|}{ Normatywny standard zapachu } \\
\hline & & $\begin{array}{c}\text { Czas narażenia } \\
\tau_{\text {uśs. }} \\
{[\mathrm{min}]}\end{array}$ & $\begin{array}{c}\text { Stężenie } \\
\text { odorantów } \\
c_{\text {od }} \\
{\left[\mathrm{ou} / \mathrm{m}^{3}\right]}\end{array}$ & $\begin{array}{c}\text { Częstość } \\
\text { przekroczeń } \\
\text { w roku } \\
{[\%]}\end{array}$ \\
\hline \multirow{4}{*}{ Holandia } & zakłady istniejące & \multirow{4}{*}{60} & \multirow{4}{*}{0,5} & 0,50 \\
\hline & zakłady nowe & & & 500 \\
\hline & odosobnione budynki mieszkalne na terenach przemysłowych & & & 5,00 \\
\hline & źródła okresowe i zmienne & & & 0,10 \\
\hline \multirow{6}{*}{ Niemcy } & obszary mieszkalne i mieszkalno-usługowe & \multirow{2}{*}{\multicolumn{2}{|c|}{$\begin{array}{c}\text { „godzina odorowa” } \\
\left(>1 \mathrm{ou} / \mathrm{m}^{3} \mathrm{przez}>1 \mathrm{~min} / 10 \mathrm{~min}\right)\end{array}$}} & 10,00 \\
\hline & obszary handlowo-przemysłowe & & & 15,00 \\
\hline & czyste obszary mieszkalne & \multirow{4}{*}{60} & \multirow{4}{*}{1,0} & 7,00 \\
\hline & obszary mieszkalne i mieszkalno-usługowe & & & 10,00 \\
\hline & wsie & & & 12,00 \\
\hline & $\begin{array}{l}\text { wsie z fermami hodowlanymi o wielkości powyżej wskazanej } \\
\text { granicy, dworce autobusowe, obszary przemysłowe }\end{array}$ & & & 15,00 \\
\hline \multirow{8}{*}{$\begin{array}{l}\text { Wielka } \\
\text { Brytania }\end{array}$} & $\begin{array}{l}\text { rafinerie ropy naftowej, oczyszczalnie ścieków, przetwórnie } \\
\text { odpadów rybnych i zwierzęcych i in. }\end{array}$ & \multirow{8}{*}{60} & 1,5 & \multirow{3}{*}{2,00} \\
\hline & przemysł spożywczy, smażalnie, hodowle bydła itp. & & 3,0 & \\
\hline & browary, piekarnie, palarnie kawy, fabryki czekolady i in. & & 6,0 & \\
\hline & $\begin{array}{l}\text { działalność o znaczącej uciążliwości spodziewanej z dużym } \\
\text { prawdopodobieństwem }\end{array}$ & & 10,0 & \multirow{3}{*}{2,00} \\
\hline & instalacje pracujące & & 5,0 & \\
\hline & brak znaczącej uciążliwości & & 1,0 & \\
\hline & nowe instalacje o charakterze stałym (wartość docelowa) & & 1,0 & 0,50 \\
\hline & nowe instalacje o charakterze zmiennym (wartość docelowa) & & 10,0 & 0,01 \\
\hline
\end{tabular}

warunków zewnętrznych oraz oddziaływań między substancjami będącymi składnikami mieszaniny zapachowej.

Analiza sensoryczna oznacza ocenę właściwości badanych próbek za pomocą jednego lub kilku zmysłów stosowanych jako ,aparat pomiarowy”. Dotyczy to pomiarów wykonywanych w sposób gwarantujący powtarzalność i odtwarzalność wyników. Jest to możliwe jedynie w przypadku rygorystycznego przestrzegania procedur znormalizowanych [17]. Precyzują one wymagania, które muszą spełniać zespoły osób oceniające zapach, odczynniki i sprzęt laboratoryjny oraz instalacje wentylacyjno-klimatyzacyjne. Określają także metody sprawdzania sensorycznej wrażliwości uczestników pomiarów, sposoby prezentacji próbek i rejestracji wyników ocen, jak również metody statystycznego opracowania wyników pomiarów.

Wiodącą techniką sensoryczną w badaniach zapachów jest olfaktometria dynamiczna. Używa się w niej olfaktometrów dynamicznych, czyli urządzeń służących do rozcieńczania strumienia badanego gazu wymieszanego ze strumieniem czystego powietrza. Zapach wylotowego strumienia mieszaniny gazu badanego z czystym gazem rozcieńczającym ocenia odpowiednio dobrany zespół ekspertów. Zgodnie z zale- ceniami normy PN-EN 13725:2007 [17] w pomiarach stężenia zapachowego wykonywanych metodą rozcieńczeń dynamicznych powinny uczestniczyć 4 osoby (eksperci) spełniające ściśle określone kryteria odnośnie do wrażliwości węchu. Ich zadaniem jest sygnalizowanie, przy którym poziomie rozcieńczenia zaczynają wyczuwać zapach badanej próbki.

Wynikiem pomiaru olfaktometrycznego jest stopień rozcieńczenia próbki badanego gazu, po którym osiągany jest zespołowy próg wyczuwalności zapachu (stężenie odorantu lub stopień rozcieńczenia próbki, przy którym zapach jest wyczuwalny z prawdopodobieństwem 0,5 , odniesiony do grupy badaczy), czyli sytuacja, gdy stężenie zapachowe odorantu lub mieszaniny odorantów jest równe jednej jednostce zapachowej w metrze sześciennym powietrza: $c_{o d}=1 \mathrm{ou} / \mathrm{m}^{3}$ [17] (inaczej mówiąc, to taka ilość odorantu, która po odparowaniu do $1 \mathrm{~m}^{3}$ obojętnego gazu w warunkach standardowych jest wyczuwalna przez członków zespołu oceniającego). Schemat budowy olfaktometru dynamicznego przedstawiony został na rysunku 1. Jego zastosowanie w pomiarach jakości zapachów wymaga, aby stopień rozcieńczenia strumienia badanej próbki strumieniem czystego powietrza obejmował zakres od $<2^{7}$ do $\geq 2^{14}$. 
Rozcieńczenie początkowe badanej próbki powinno być tak duże, żeby jej zapach nie był wyczuwalny. Kolejne, zmniejszające się rozcieńczenia (a tym samym zwiększanie stężenia środka zapachowego/ odorantu w mieszaninie z powietrzem) uzyskuje się przez zmiany przepływów gazów.

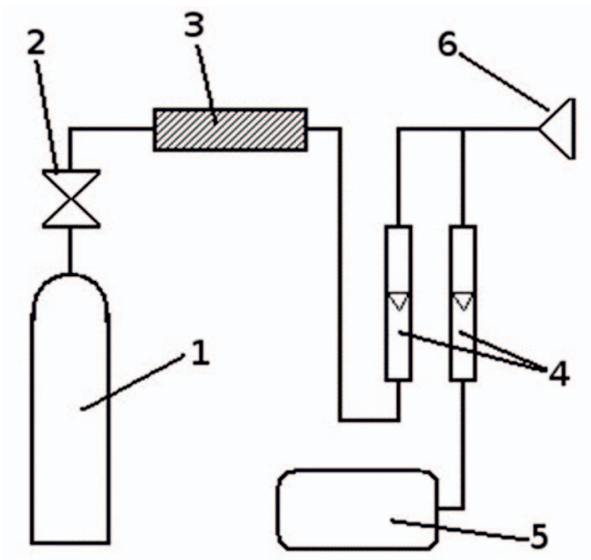

Rys. 1. Schemat ideowy oznaczania stężenia zapachu przy użyciu olfaktometru dynamicznego: 1 - butla $\mathrm{z}$ bezwonnym powietrzem, 2 - zawór, 3 - filtr, 4 - rotametry, 5 - oznaczana próbka gazów, 6 - lejek węchowy

W olfaktometrach dynamicznych wytwarzane są zatem tzw. serie rozcieńczeń badanego gazu. Seria jest tworzona przez rozcieńczanie próbki w stopniu $Z$, stanowiącym szereg geometryczny: $1280,640,320,160,80, \ldots$ (szereg o kroku 2). Próbki serii rozcieńczeń mogą być prezentowane zespołowi uczestników do oceny w różnej kolejności, np. losowo lub ,sekwencyjnie w górę", czyli kolejno, rozpoczynając od najbardziej rozcieńczonych. Po obróbce zebranych wyników pomiarów uzyskuje się wynik średni (np. z trzech serii pomiarowych). Oceny jakości zapachu dokonywane są metodą TAK/NIE lub na zasadzie testów różnicowych (strumień gazu badanego jest prezentowany równocześnie z jednym lub dwoma strumieniami czystego powietrza). Zgodnie z normą w każdej serii muszą się znajdować „ślepe próby” (prezentacja powietrza odniesienia zamiast próbki; co najmniej 20\% wszystkich prezentacji w serii).

W metodach rozcieńczeń zakłada się, że krotność rozcieńczenia do uzyskania zaniku zapachu jest miarą pierwotnego natężenia zapachu. Otrzymana wartość stopnia rozcieńczenia, przy której co najmniej 50\% uczestników potwierdza odczuwanie reakcji węchowej na zapach danej próbki, uznaje się za wynik pomiaru. Jest to zespołowy próg wyczuwalności zapachu, wyrażany zależnością:

$$
c_{\text {od }}=Z_{50 \%} \cdot 1 \mathrm{ou} / \mathrm{m}^{3}=\bar{Z}_{\text {ITE,pan }} \cdot 1 \mathrm{ou} / \mathrm{m}^{3}
$$

gdzie:

$c_{o d}$ - stężenie zapachowe, wartość odniesienia dla serii rozcieńczeń (tu: wartość stężenia gazu badanego wynikająca z rozcieńczenia),
$Z_{50 \%}$ - stopień rozcieńczenia próbki na progu wyczuwalności 50\%,

$\bar{Z}_{I T E, p a n}$ - średnia geometryczna ocen progu indywidualnego, wyrażonych jako stopień rozcieńczenia, dla wszystkich uprawnionych członków zespołu po weryfikacji.

W toku wcześniejszych prac prowadzonych w Zakładzie Nawaniania Paliw Gazowych INiG - PIB skonstruowano oraz zweryfikowano działanie przystawki odorymetrycznej INiG - PIB (O INiG - PIB) [9-11]. Dotychczas dowiedziono możliwości jej stosowania w zakresie badań odorymetrycznych gazów ziemnych nawonionych tetrahydrotiofenem (THT) oraz syntetycznego powietrza atmosferycznego zanieczyszczonego lotnymi związkami siarki [9-11]. W toku realizacji kolejnego etapu badań podjęto próbę dostosowania istniejącego prototypu do wykonywania pomiarów metodą olfaktometrii dynamicznej. Zrealizowanie takiej modyfikacji rozszerzy możliwości pomiarowe urządzenia o badania środowiskowe powietrza atmosferycznego.

Zasada działania przystawki odorymetrycznej INiG - PIB polega na mieszaniu gazu badanego z powietrzem bezwonnym w ściśle określonych proporcjach i poddawaniu uzyskanej mieszaniny ocenie sensorycznej (opisano to szerzej we wcześniejszych publikacjach [9-11]). Jest to zgodne z wymaganiami stawianymi olfaktometrom dynamicznym [17]. Jedyną różnicę stanowi zakres rozcieńczeń, jakie można uzyskać w skonstruowanej pierwotnie przystawce O INiG - PIB i powszechnie stosowanych olfaktometrach dynamicznych. Przystawka jest bowiem „olfaktometrem” o specyficznym, wąskim zakresie możliwych do uzyskania rozcieńczeń badanej próbki.

Aby można było przy użyciu przystawki odorymetrycznej O INiG - PIB prowadzić badania zapachu metodą olfaktometrii dynamicznej, konieczne było dostosowanie układu regulacji i kontroli przepływu gazu badanego do szerokiego zakresu rozcieńczeń. Przyjęto docelowy zakres rozcieńczeń od 128 do 16 384, co odpowiada stężeniu gazu badanego (próbki) w mieszaninie poddawanej ocenom zapachu mieszczącemu się w zakresie: 0,006\% do 0,78\% ( $V / V)$. Wynika on z wymagań normy PN-EN 13725:2007 [17], dopuszczającej zakres rozcieńczeń dla olfaktometrów od $2^{7}$ do co najmniej $2^{14}$. Zgodnie wymaganiami normatywnymi [17] zakres między rozcieńczeniem maksymalnym i minimalnym powinien wynosić co najmniej $2^{13}$. Jest to zakres rozcieńczeń próbki bezwzględnie wymagany do ocen uciążliwości zapachu.

Modyfikacją wprowadzoną w prototypie przystawki odorymetrycznej O INiG - PIB [9-11] było zainstalowanie drugiego ciągu regulacyjnego/pomiarowego gazu badanego, który spełnia wymagania odnośnie do zakresu możliwych ustawień, charakterystycznego dla olfaktometrów dynamicznych. 
Do regulacji przepływu gazu zastosowano cyfrowy przepływomierz masowy. Ustalono też konkretne wartości przepływu gazu badanego, odpowiadające żądanym poziomom rozcieńczeń próbki, ocenianym sensorycznie przez zespół ekspertów.

\section{Weryfikacja zmodyfikowanego układu według kryteriów normatywnych}

W celu wykazania poprawności modyfikacji przystawki odorymetrycznej O INiG - PIB dla zastosowań olfaktometrii dynamicznej dokonano weryfikacji działania zaprojektowanego i opisanego powyżej układu pomiarowego na zgodność z wymaganiami określonymi w PN-EN 13725:2007 [17]. Zgodnie z nimi sprzęt do rozcieńczania powinien spełniać dwa kryteria, to jest kryterium dokładności i niestabilności rozcieńczeń.

Dokładność serii rozcieńczeń $\left(A_{d}\right)$ powinna spełniać warunek:

$$
A_{d}=\frac{\left|d_{w, d}\right|+\left(A_{w, d} \cdot r_{d}\right)}{\mu_{d}} \leq 0,20
$$

gdzie:

$\mu_{d}$ - wartość odniesienia dla serii rozcieńczeń (tu: wartość stężenia gazu badanego wynikająca z rozcieńczenia),

$A_{w, d}$ - współczynnik statystyczny,

$d_{w, d}$ - poprawność, wyrażona jako oszacowanie obciążenia serii rozcieńczeń,

$r_{d} \quad$ - granica powtarzalności.

Obciążenie serii rozcieńczeń $\left(d_{w, d}\right)$ należy obliczyć z:

$$
d_{w, d}=\bar{y}_{w d}-\mu_{d}
$$

gdzie: $\bar{y}_{w d}$ stanowi średnią wyników pomiarów (jeden wynik pomiarów $y$ jest średnią zaobserwowanych wartości dla jednej serii), a granicę powtarzalności $r_{d} \mathrm{z}$ :

$$
r_{d}=t \cdot \sqrt{2} \cdot s_{r, d}
$$

gdzie: $t$ oznacza współczynnik rozkładu $t$-Studenta dla $n-1$ stopni swobody i 95-proc. poziomu ufności.
Niestabilność rozcieńczenia $\left(I_{d}\right)$ dla „prezentacji” $i$ (prezentacja rozumiana jest jako przedstawienie do oceny jednego rozcieńczenia jednemu oceniającemu) jest obliczana jako prawdopodobieństwo wykroczenia poza dwustronny przedział na 95-proc. poziomie ufności ze wzoru:

$$
I_{d}=\frac{1,96 \cdot s_{I, d}}{y_{i, d}} \cdot 100 \%
$$

gdzie:

$y_{i, d}-$ średnia wyników z serii pomiarowej,

$s_{I, d}$ - odchylenie standardowe serii pomiarowej.

Norma PN-EN 13725:2007 [17] jako kryterium niestabilności rozcieńczeń $I_{d}$ podaje $I_{d}<5 \%$.

W tablicy 2 dokonano podsumowania ww. parametrów jakościowych wyznaczonych dla zmodyfikowanego układu odorymetrycznego. Pomiary wykonano dla serii rozcieńczeń próbki badanej, wynikającej z przyjętego założenia konstrukcyjnego. Jako gazu testowego użyto metanu rozcieńczanego powietrzem (zgodnie z przeznaczeniem testowanego urządzenia). Uzyskano następujące wyniki niestabilności i dokładności dla zmodyfikowanego układu:

- średni parametr niestabilności rozcieńczeń $I_{d} \mathrm{~W}$ zakresie $3,03 \div 4,88 \%$ (wymagane $<5 \%$ ),

- parametr dokładności rozcieńczeń $A_{d}$ w zakresie $0,07 \div 0,18$ (wymagane $\leq 0,20$ ).

Otrzymane wyniki pomiarów dowodzą zatem, że wymagania normy PN-EN 13725:2007 [17] dotyczące niestabilności $\left(I_{d}<5 \%\right)$ oraz dokładności rozcieńczeń $\left(A_{d} \leq 0,20\right)$ dla urządzeń rozcieńczających (olfaktometrów) zostały spełnione dla projek-

\begin{tabular}{|c|c|c|c|c|c|c|}
\hline \multirow[b]{2}{*}{ Rozcieńczenie $Z$} & \multicolumn{3}{|c|}{ Niestabilność } & \multicolumn{3}{|c|}{ Dokładność } \\
\hline & $\begin{array}{c}\text { obliczona } \\
\bar{I}_{d}\end{array}$ & $\begin{array}{c}\text { wartość } \\
\text { krytyczna } I_{d}\end{array}$ & $\begin{array}{c}\text { ocena } \\
\text { wymagania }\end{array}$ & $\begin{array}{c}\text { obliczona } A_{d} \\
{[-]}\end{array}$ & $\begin{array}{c}\text { wartość krytyczna } A_{d} \\
{[-]}\end{array}$ & $\begin{array}{c}\text { ocena } \\
\text { wymagania }\end{array}$ \\
\hline 128 & 3,03 & \multirow{8}{*}{5} & \multirow{8}{*}{ spełnione } & 0,18 & \multirow{8}{*}{0,20} & \multirow{8}{*}{ spełnione } \\
\hline 256 & 3,31 & & & 0,07 & & \\
\hline 512 & 4,88 & & & 0,12 & & \\
\hline 1024 & 4,15 & & & 0,15 & & \\
\hline 2048 & 4,63 & & & 0,13 & & \\
\hline 4096 & 3,11 & & & $\mathbf{0 , 0 7}$ & & \\
\hline 8192 & 4,82 & & & 0,06 & & \\
\hline 16384 & 3,91 & & & 0,16 & & \\
\hline
\end{tabular}
tu przystawki zmodyfikowanej do funkcji olfaktometrycznej.

Tablica 2. Zestawienie wyników oceny kryterium stabilności i dokładności rozcieńczeń dla przystawki odorymetrycznej INiG - PIB zmodyfikowanej do funkcji olfaktometrycznej (gaz testowy $-\mathrm{CH}_{4}$ ) 


\section{Oznaczenie stężenia zapachowego syntetycznych próbek powietrza}

W ramach prac badawczych zmodyfikowanej przystawki odorymetrycznej O INiG - PIB przeprowadzono oznaczenia stężenia zapachowego dla trzech syntetycznych próbek powietrza zawierających wybrany związek zapachowy w stężeniu powodującym prognozowaną uciążliwość zapachową (dobór stężenia na podst. literatury [8]):

- 7 ppm tetrahydrotiofenu w azocie,

- 2 ppm siarkowodoru w azocie,

- 2 ppm merkaptanu metylowego w azocie.

Dla każdej próbki przeprowadzono 4 cykle pomiarowe z udziałem zespołu oceniającego (ekspertów) Zakładu Nawaniania Paliw Gazowych INiG - PIB, posiadających długoletnie doświadczenie w prowadzeniu pomiarów jakości zapachu gazów. Grupa składała się z 4 osób, spełniających wymagania normy [17], i została dobrana i sprawdzona zgodnie z jej wymaganiami.

$\mathrm{W}$ celu uzyskania oceny progu indywidualnego $\left(\mathrm{Z}_{I T E}\right)$ wyczuwania zapachu (odniesionego do jednej osoby) ekspertów proszono o ocenę zapachu gazu wypływającego z lejka olfaktometru i stwierdzenie jego wyczuwania (odpowiedź: „TAK” lub „NIE”). Oceniający był świadomy, że w niektórych przypadkach prezentowane są próbki ślepe (co najmniej jedna próbka ślepa na cykl pomiarowy w losowej pozycji w porządku prezentacji). Ekspert w ciągu 15 sekund oceniał prezentowany bodziec. Seria rozcieńczeń zawierała co najmniej dwie kolejne odpowiedzi „TAK” dla dwóch prezentacji z najwyższym stężeniem odoran- tu. Dla każdego z uczestników pomiarów obliczono cztery wartości $Z_{I T E}$, czyli stopnie rozcieńczenia odpowiadające osiągnięciu progu wyczuwalności zapachu w każdym cyklu. Wartości te obliczano jako średnie geometryczne z najmniejszego spośród $Z_{\text {nie }}$ (rozcieńczenia próbki, której zapach nie jest wyczuwalny) i największego $Z_{\text {tak }}$ (rozcieńczenia próbki, której zapach jest wyczuwalny), po którym następuje kolejne $Z_{\text {tak }}$.

Wyniki oznaczania stężenia zapachowego poszczególnych próbek syntetycznych powietrza atmosferycznego, otrzymane zgodnie z wytycznymi normy PN-EN 13725:2007 [17], na podstawie wyznaczonych stopni rozcieńczeń, były następujące: - $7 \mathrm{ppm}$ tetrahydrotiofenu w azocie $-412 \mathrm{ou}_{\mathrm{E}} / \mathrm{m}^{3}$,

- 2 ppm siarkowodoru w azocie $-1649 \mathrm{ou}_{\mathrm{E}} / \mathrm{m}^{3}$,

- 2 ppm merkaptanu metylowego $\mathrm{w}$ azocie $-5547 \mathrm{ou}_{\mathrm{E}} / \mathrm{m}^{3}$.

Uzyskane wyniki stężenia zapachowego odorantu (THT) odniesiono do jednostki masy europejskiego wzorca zapachu (EROM). Dla europejskiej jednostki zapachowej ustalono jako wartość odniesienia EROM równą $123 \mu \mathrm{g}$ n-butanolu. Po odparowaniu EROM do $1 \mathrm{~m}^{3}$ obojętnego gazu stężenie n-butanolu wynosi $0,040 \mu \mathrm{mol} / \mathrm{mol}: 1 \mathrm{EROM}=123 \mu \mathrm{g}$-butanolu $=1 \mathrm{ou}_{\mathrm{E}}$ mieszaniny odorantów.

Przedstawione powyżej wyniki potwierdziły możliwość wykonywania pomiarów jakości zapachu próbek powietrza z użyciem zmodyfikowanego układu pomiarowego INiG - PIB z zachowaniem wymagań stawianych pomiarom olfaktometrycznym [17].

\section{Podsumowanie}

W niniejszej publikacji przedstawiono wyniki prac podjętych przez Zakład Nawaniania Paliw Gazowych INiG - PIB w zakresie dostosowania konstrukcji własnej przystawki odorymetrycznej O INiG - PIB do wymagań oznaczania stężenia zapachu metodą olfaktometrii dynamicznej.

Podsumowując, należy stwierdzić, że w wyniku prac badawczych:

- określono koncepcję modyfikacji przystawki odorymetrycznej INiG - PIB do metody olfaktometrii dynamicznej. Dokonano niezbędnych modyfikacji posiadanego prototypu oraz wyznaczono korelację wskazań zmodyfikowanego układu z wymaganiami normatywnymi [17];

- zweryfikowano pozytywnie działanie zmodyfikowanego układu pod względem spełniania kryteriów badania zapachu metodą olfaktometrii dynamicznej [17] na podsta- wie wyznaczonych parametrów dokładności i niestabilności rozcieńczeń;

- na podstawie normy PN-EN 13725:2007 [17] opracowano wytyczne prowadzenia pomiarów olfaktometrycznych w układzie sprzężonym GC-O INiG - PIB;

- za pomoca zmodyfikowanej przystawki odorymetrycznej INiG - PIB oznaczono stężenie zapachowe dla syntetycznych próbek powietrza atmosferycznego zawierających zanieczyszczenia odorowe, zgodnie z wymaganiami normatywnymi [17]

Uzyskane wyniki pomiarów potwierdziły zgodność działania zaprojektowanego układu GC-O INiG - PIB z wymaganiami stawianymi urządzeniom przeznaczonym do pomiarów olfaktometrycznych oraz możliwość jego wykorzystania w badaniach jakości zapachowej powietrza atmosferycznego.

Prosimy cytować jako: Nafta-Gaz 2018, nr 11, s. 839-845, DOI: 10.18668/NG.2018.11.08

Artykuł nadesłano do Redakcji 9.07.2018 r. Zatwierdzono do druku 7.12.2018 r. 
Artykuł powstał na podstawie pracy statutowej pt. Modyfikacja prototypu przystawki odorymetrycznej INiG - PIB na potrzeby wykonywania pomiarów metoda olfaktometrii dynamicznej - praca INiG - PIB na zlecenie MNiSW; nr zlecenia: 0082/WN/17/01, nr archiwalny: DK-4100-69/17.

\section{Literatura}

[1] Bokowa A.: Ambient Odour Assessment Similarities and Differences Between Different Techniques. Chemical Engineering Transaction 2012, vol. 30, s. 313-318.

[2] Brattoli M., de Gennaro G., de Pinto V., Loiotile A.D., Lovascio S., Penza M.: Odour Detection Methods: Olfactometry and Chemical Sensors. Sensors 2011, vol. 11, nr 5, s. 5290-5322.

[3] Dudek J.: Analiza zagrożén emisja biogazu na terenie po zrekultywowanym składowisku odpadów komunalnych w Krośnie. Nafta-Gaz 2011, nr 8, s. 562-567.

[4] Gaja K., Kuropka J. (red.): Powietrze atmosferyczne: jakośćzagrożenia - ochrona. Oficyna Wydawnicza Politechniki Wrocławskiej, Wrocław 2016.

[5] Kolasińska P., Dymerski T., Namieśnik J.: Metody analizy sensorycznej jako narzędzie do oceny uciążliwości zapachowej powietrza atmosferycznego. Cz. I-podstawy teoretyczne. Analityka 2015, nr 4, s. 8-11.

[6] Kolasińska P., Dymerski T., Namieśnik J.: Metody analizy sensorycznej jako narzędzie do oceny uciążliwości zapachowej powietrza atmosferycznego. Cz. II - charakterystyka metod analizy sensorycznej. Analityka 2016, nr 1, s. 4-10.

[7] Kolasińska P., Dymerski T., Namieśnik J.: Metody analizy sensorycznej jako narzędzie do oceny uciążliwości zapachowej powietrza atmosferycznego. Cz. III - zastosowania. Analityka 2016, nr 1, s. 48-53.

[8] Kośmider J., Mazur-Chrzanowska B., Wyszyński B.: Odory. Wydawnictwo Naukowe PWN, Warszawa 2002.

[9] Lisman S., Huszał A.: Badania jakości gazów ziemnych przy użciu przystawki odorymetrycznej INiG - PIB sprzężonej $z$ analizatorem chromatograficznym wyposażonym $w$ detektor

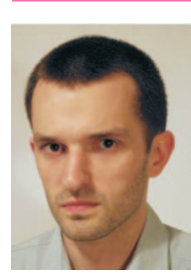

Mgr inż. Szymon LISMAN

Specjalista inżynieryjno-techniczny w Zakładzie

Nawaniania Paliw Gazowych

Instytut Nafty i Gazu - Państwowy Instytut Badawczy

ul. Lubicz 25 A

31-503 Kraków

E-mail: szymon.lisman@inig.pl elektrochemiczny. Nafta-Gaz 2015, nr 12, s. 1024-1029, DOI: 10.18668/NG2015.11.11.

[10] Lisman S., Huszał A.: Badanie zależności zapachowej jakości powietrza od zawartości zanieczyszczeń siarkowych z użyciem przystawki odorymetrycznej INiG - PIB. Nafta-Gaz 2016, nr 7, s. 539-545, DOI: 10.18668/NG.2016.07.07.

[11] Lisman S., Huszał A.: Dostosowanie prototypu przystawki odorymetrycznej sprzężonej z chromatografem gazowym do oznaczeń zapachowej jakości gazów. Nafta-Gaz 2015, nr 3, s. $190-194$.

[12] Loriato A.G., Salvador N., Santos J.M., Moreira D.M., Reis Jr N.C.: Odour. A vision on the existing regulation. Chemical Engineering Transactions 2012, vol. 30, s. 25-30.

[13] Muñoz R., Sivret E.C., Parcsi G., Lebrero R., Wang X., Suffet I.H., Stuetz R.M.: Monitoring techniques for odour abatement assessment. Water Research 2010, vol. 44, nr 18, s. 5129-5149.

[14] Niemczewska J.: Metodyka pomiarów emisji gazów ze składowisk odpadów komunalnych. Nafta-Gaz 2013, nr 8, s. 613-618.

[15] Sówka I.: Metody identyfikacji odorotwórczych gazów emitowanych z obiektów przemysłowych. Oficyna Wydawnicza Politechniki Wrocławskiej, Wrocław 2011.

[16] Zarra T., Reiser M., Naddeo V., Belgiorno V., Kranert M.: Odour Emissions Characterization from Wastewater Treatment Plants by Different Measurement Methods. Chemical Engineering Transaction 2014, vol. 40, s. 37-42.

\section{Akty prawne i normatywne}

[17] PN-EN 13725:2007 Jakość powietrza. Oznaczanie stężenia zapachowego metoda olfaktometrii dynamicznej.

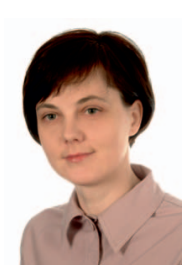

Dr Anna HUSZAŁ

Adiunkt; kierownik Zakładu Nawaniania Paliw

Gazowych

Instytut Nafty i Gazu - Państwowy Instytut Badawczy ul. Lubicz 25 A

31-503 Kraków

E-mail:anna.huszal@inig.pl 